\title{
Penyerupa dan Penyerta Tuberkulosis Paru yang Terdiagnosis Berdasarkan Gambaran CT-scan Toraks Pada Rumah Sakit Rujukan Tersier
}

\section{Mimicker and Co-existent of Pulmonary Tuberculosis on Patients Diagnosed by Thorax CT-Scan at Tertiary Referral Hospital}

\author{
Nur Amelia Bachtiar ${ }^{1}$, Sri Asriyani ${ }^{1}$, Bachtiar Murtala ${ }^{1}$, Nikmatia Latief ${ }^{1}$, Irawaty Djaharuddin², \\ Andi Alfian Zainuddin ${ }^{3}$ \\ ${ }^{1}$ Department of Radiology, Faculty of Medicine, Hasanuddin University, South Sulawesi \\ ${ }^{2}$ Department of Pulmonology, Faculty of Medicine, Hasanuddin University, South Sulawesi \\ ${ }^{3}$ Department of Public Health, Faculty of Medicine, Hasanuddin University, South Sulawesi \\ Jalan Perintis Kemerdekaan Km.10, South Sulawesi \\ Correspondence: Email: nuramelia.bachtiar@gmail.com
}

\begin{abstract}
Abstrak
Latar belakang: Sistem rujukan berjenjang dapat mempengaruhi karakteristik lesi pada CTscan toraks pasien terduga tuberkulosis (TB) paru pada rumah sakit rujukan tersier. Hal ini dapat menyamarkan keberadaan penyerupa dan penyerta TB paru. Metode Penelitian: Sampel adalah pasien yang terdiagnosis TB paru oleh ahli radiologi pada periode Oktober 2018 hingga Juni 2019. Analisis Chi-square dilakukan untuk menguji kesesuain 12 karakteristik CT-scan toraks (Konsolidasi, kavitas, tree-in-bud, fibrokalsifikasi, air-bronchogram-sign, lesi noduler, efusi pleura, atelektasis, bercak infiltrat, lymphadenopathy, bronchiectasis, ground glass opacity) dengan diagnosis akhir klinisi. Pencatatan penyerupa dan penyerta TB dilakukan setelah diagnosis akhir ditegakkan. Hasil: Dari 137 sampel, hanya $61(44.5 \%)$ pasien yang terdiagnosis sebagai TB paru aktif, 38 (27.7\%) terdiagnosis sebagai bekas TB paru dan $38(27.7 \%)$ lainnya terdiagnosis sebagai penyakit paru bukan tuberkulosis. Dari 12 variabel yang dievaluasi, karakteristik yang sesuai dengan diagnosis klinisi adalah tree-in-bud $(p=0.019)$ dan lymphadenopathy $(p=0.039)$. Penyakit penyerupa dan penyerta terbanyak adalah tumor paru dan infected bronchiectasis. Simpulan: Gambaran CT-scan pasien TB paru sangat beragam pada rumah sakit rujukan tersier. Diperlukan ketelitian ahli radiologi dan kerja sama yang baik dengan klinisi untuk mendeteksi berbagai kemungkinan diagnosis yang dapat menyerupai dan menyertai TB paru.
\end{abstract}

Kata kunci: Tuberkulosis paru; Gambaran CT-scan; Penyerupa; Penyerta

\section{Abstract}

Background: Multitiered referral scheme in Indonesian hospitals might affect the lesion's characteristics on the chest CT-scan of patients with suspected pulmonary tuberculosis (PTB) in tertiary hospital. This might obscure the presence of mimicker and co-existent of PTB in this population. Method: Subjects were patients diagnosed with PTB by radiologists from October 2018 - June 2019. We evaluate presence of consolidation, cavity, tree-in-bud, fibro-calcification, air-bronchogram-sign, 
nodule, pleural effusion, atelectasis, infiltrate, lymphadenopathy, bronchiectasis, and ground glass opacity using RadiAnt program. We analyze their relationship with clinician's final diagnosis using Chisquare test. Results: Out of 137 samples, 61 (44.5\%) and 38 (27.7\%) were diagnosed as active PTB and non-active PTB by clinicians while other 38 (27.7\%) were diagnosed with other diseases. From 12 characteristics observed, only tree-in-bud $(p=0.019)$ and lymphadenopathy $(p=0.039)$ were significantly related. Of 38 (27.7\%) patients not diagnosed as PTB, lung tumor, infected bronchiectasis, and pneumonia were the most common mimicker. For those diagnosed as TB by clinician, most found PTB co-existent were lung tumor, infected bronchiectasis, dan metastasis. Conclusion: CT-scan features of PTB patients can be confusing in tertiary hospitals. Radiologist and clinician should work together and be more careful in considering possible presence of PTB mimickers and co-existent.

Keywords: Pulmonary tuberculosis; CT-scan features; mimicker; co-existent

\section{Pendahuluan}

Indonesia merupakan salah satu dari delapan negara penyumbang $2 / 3$ dari seluruh insidens Tuberkulosis (TB) di dunia, Indonesia menempati posisi ke-2 di dunia dengan tingkat insidens sebanyak 842.000 orang pada tahun 2017 (WHO, 2018). Hal ini mengimplikasikan pentingnya penelitian bertema TB di negara Indonesia.

Menurut Anung Sugihantono, terdapat tiga hal yang menjadi fokus dalam penanganan masalah tuberkulosis di Indonesia, ketiga hal tersebut adalah deteksi missing case, perbaikan kepatuhan konsumsi obat, dan resistensi obat (Sugihantono, 2018).

Dalam Keputusan Menteri Kesehatan Republik Indonesia Nomor 364/MENKES/SK/V/2009 tentang Pedoman Penanggulangan Tuberkulosis (TB) Menteri Kesehatan Republik Indonesia (2009), penegakan diagnosis TB masih terbatas pada hasil pemeriksaan klinis, pemeriksaan laboratorium sputum BTA dan foto $X$-ray toraks konvensional. Sementara itu, CT scan belum menjadi modalitas standar, karena biayanya yang mahal dan tidak tersedia di berbagai pusat pelayanan kesehatan primer. Namun CT-scan dianggap memiliki kelebihan dalam mendiagnosis lesi-lesi minimal, membedakan kondisi aktif dan non-aktif, menilai perluasan endobronkial, serta mendiagnosis TB paru dengan hasil pemeriksaan sputum bakteri tahan asam (BTA) negatif secara lebih baik (Kementrian Kesehatan Republik Indonesia, 2014; Icksan, 2017; Lee, 2010).

Dalam peraturan Menteri Kesehatan Republik Indonesia Nomor 56 Tahun 2014, terdapat klasifikasi yang membagi rumah sakit umum dalam kategori $A, B, C$ dan $D$ dimana rumah sakit tipe $A$ adalah jenjang rujukan tertinggi dan yang paling superior dalam hal ketersediaan jenis pelayanan, sumber daya manusia, peralatan, bagunan dan prasarana. Oleh karena itu, rumah sakit tipe A seperti RS. Wahidin Sudirohusodo (RSWS) memegang peranan yang sangat penting sebagai pusat rujukan dari berbagai rumah sakit daerah dalam program penanganan TB. Akan tetapi, sifat rujukan yang berjenjang ini membuat pasien yang datang pada RS. RSWS menjadi lebih kompleks dan seringkali sudah disertai dengan berbagai co-existent, riwayat gagal berobat, MDR, dan komplikasi dari berbagai penyakit lainnya. Karakteristik pasien yang kompleks ini 
dapat mempengaruhi gambaran yang dapat ditemukan pada pemeriksaan CT-scan pasien TB paru yang dirawat di RS. RSWS. Oleh karena itu, penelitian ini bertujuan untuk mendeskripsikan berbagai karakteristik gambaran CT scan pada pasien yang terdiagnosis TB paru oleh ahli radiologi yang disesuaikan dengan hasil keputusan klinisi, Selain itu, penelitian ini juga akan mendeskripsikan diagnosis penyerta (coexistent) dan penyerupa (mimicker) tuberkulosis (Menteri Kesehatan Republik Indonesia, 2014).

\section{Bahan dan Metoda Penelitian}

Desain penelitian ini adalah penelitian cross-sectional retrospektif untuk mengetahui kesesuaian berbagai karakteristik gambaran TB paru berdasarkan CT scan toraks dengan diagnosis akhir klinisi. Penelitian ini dilakukan di Bagian Radiologi RS. RSWS dengan mengambil data sekunder pasien yang terdiagnosis TB paru oleh ahli radiologi pada bulan Oktober 2018 hingga Juni 2019.

Populasi adalah pasien yang dikirim ke bagian Radiologi RS RSWS untuk menjalani pemeriksaan CT scan toraks dan terjawab sebagai pasien TB paru aktif oleh ahli radiologi. Pasien kemudian diikuti hingga ditegakkan diagnosis akhir berupa diagnosis primer (TB atau bukan TB) dan diagnosis sekunder oleh klinisi bagian pulmonologi RS. RSWS. Pada pasien yang terdiagnosis sebagai TB paru akitf oleh klinisi dan mendapatkan pengobatan OAT serta dinyatakan memberikan respon yang baik, kami melakukan pencatatan mengenai berbagai penyakit paru yang menyertai pasien (coexistent). Selanjutnya, pasien yang terdiagnosis sebagai bukan TB paru aktif oleh klinisi, telah kami lakukan pencatatan mengenai penyakit paru apa yang terdiagnosis oleh klinisi bagian pulmonologi (mimicker).

Variabel tergantung (dependent) dalam penelitian ini adalah diagnosis akhir berupa "TB paru aktif" atau "Bukan TB paru". Variabel bebas (independent) dalam penelitian ini adalah dua belas karakteristik gambaran radiologi yang dapat dinilai berdasarkan CT-scan toraks pada pasien yang telah dijawab sebagai TB paru oleh ahli radiologi. Karakteristik yang dinilai adalah ada atau tidak adanya: Konsolidasi, kavitas, treein-bud sign, fibrokalsifikasi, air-bronchogramsign, lesi noduler, efusi pleura, atelektasis, bercak infiltrate, lymphadenopathy, bronchiectasis, dan ground-glass appearance (GGO). Sebagai bentuk standarisasi, peneliti melakukan pembacaan ulang seluruh file CTscan (dalam bentuk DICOM) pasien dengan menggunakan program RadiAnt dan diverifikasi oleh seorang ahli radiologi konsultan toraks. Variabel ini kemudian kami analisis hubungan dengan tes komparasi chi-square.

\section{Hasil Penelitian}

Selama periode 9 bulan penelitian, terdapat 310 pasien yang terdiagnosis sebagai TB paru aktif oleh ahli radiologi, 99 (31.93\%) pasien tidak dapat dimasukkan dalam penelitian karena tidak terdapat hasil pemeriksaan laboratorium minimal untuk identifikasi TB paru seperti sputum BTA. Sebanyak 53 pasien (17.09\%) tidak dapat diteliti karena data file CT scan pasien hilang, dan sebanyak 21 pasien $(6.77 \%)$ tidak dapat dimasukkan dalam pengolahan data karena tidak terdapat kepastian diagnosis (inconclusive) akibat pasien yang tidak kembali untuk kontrol, atau meninggal sebelum diberikan pengobatan obat anti tuberkulosis (OAT). Pada akhirnya tersisa 137 sampel yang dapat diolah dalam penelitian ini. 
Dari 137 sampel yang memenuhi syarat kriteria inklusi, sebanyak 121 (88.83\%) sampel memiliki hasil pemeriksaan sputum BTA yang negatif, sementara itu hanya terdapat 16 sampel $(11.67 \%)$ yang memiliki hasil pemeriksaan sputum BTA yang positif (Tabel 1).

Berdasarkan keputusan diagnosis akhir oleh klinisi dengan mempertimbangkan hasil pemeriksaan laboratorium, gejala klinis, dan pemeriksaan lainnya, terdapat 61 sampel $(44.50 \%)$ yang pada akhirnya mendapatkan diagnosis TB paru aktif dan tercatat mendapatkan dan berespon baik terhadap terapi OAT. Sementara itu terdapat 76 sampel (55.5\%) yang dianggap tidak menderita TB paru aktif. Dari 76 sampel tersebut, terdapat 38 sampel (28\%) yang memiliki riwayat menderita TB paru dan mengonsumsi OAT sebelumnya, sehingga hanya terdapat 38 sampel (28\%) saja yang tidak memiliki riwayat menderita TB paru sebelumnya dan tidak didiagnosis sebagai TB paru aktif saat ini (Tabel 1).

Tabel 1. Sebaran Karakteristik Sampel Penelitian

\begin{tabular}{lcc}
\hline Karakteristik sampel & Jumlah & Persentase (\%) \\
\hline Diagnosis Klinisi & & \\
TB paru aktif & 61 & 44.5 \\
Bekas TB paru & 38 & 27.7 \\
Bukan TB paru & 38 & 27.7 \\
Sputum BTA & 16 & 11.6 \\
Positif & 121 & 88.8 \\
Negatif & & \\
Jenis kelamin & 83 & 60.50 \\
Laki-laki & 54 & 39.41 \\
Perempuan & & \\
Kelompok umur & 35 & 25.50 \\
< 40 tahun & 102 & 74.45 \\
$\geq 40$ tahun & &
\end{tabular}

Tabel 2. Hubungan antara berbagai karakteristik gambaran ct scan dengan diagnosis klinisi

\begin{tabular}{|c|c|c|c|}
\hline \multirow[b]{2}{*}{ Gambaran CT scan } & \multicolumn{2}{|c|}{ Diagnosis Klinisi } & \multirow[b]{2}{*}{$p$-value } \\
\hline & $\begin{array}{c}T B \\
(n=61)\end{array}$ & $\begin{array}{c}\text { Bukan TB } \\
(n=76)\end{array}$ & \\
\hline Konsolidasi & 57 & 68 & 0.608 \\
\hline Kavitas & 40 & 51 & 0.995 \\
\hline Tree-in-bud & 56 & 57 & $0.019^{*}$ \\
\hline Fibrokalsifikasi & 52 & 68 & 0.627 \\
\hline Air-bronchogram Sign & 51 & 58 & 0.402 \\
\hline Lesi noduler & 51 & 61 & 0.779 \\
\hline Efusi pleura & 36 & 49 & 0.633 \\
\hline Atelektasis & 35 & 38 & 0.492 \\
\hline Bercak infiltrate & 61 & 72 & 0.191 \\
\hline Lymphadenopathy & 29 & 22 & $0.039^{*}$ \\
\hline Bronchiectasis & 42 & 61 & 0.181 \\
\hline Ground glass opacity & 50 & 66 & 0.583 \\
\hline
\end{tabular}

Sumber: data primer, keterangan: Uji Chi-Square, ${ }^{*} p<0.05$ 
Secara demografis, jumlah sampel dengan jenis kelamin laki-laki tampak lebih banyak daripada jumlah perempuan yaitu sebanyak 83 (60.5\%) banding 54 (39.41\%). Berdasarkan karakteristik umur sampel, sebagian besar sampel berasal dari golongan umur 40 tahun keatas dengan jumlah 102 (74.45\%) berbanding $35(25.50 \%)$ pada sampel dengan golongan umur kurang dari 40 tahun (Tabel 1).

Hubungan antara berbagai gambaran ct scan dengan diagnosis klinisi dapat terlihat pada tabel 2. Pada tabel dapat terlihat bahwa hanya terdapat dua variabel yang bermakna yaitu Treein-bud ( $p$-value $=0.019$ ) dan lymphadenopathy $(p$-value $=0.039)$. Sementara itu, gambaran karakteristik CT-scan lain seperti kavitas, lesi noduler, dan konsolidasi merupakan karakteristik yang tidak berhubungan dengan diagnosis klinisi.

Tabel 3 menggambarkan mengenai penyakit yang dapat menyerupai TB paru. Tumor paru $(n=18)$ merupakan penyakit mimicker dengan frekuensi terbanyak. Infected bronchiectasis $(\mathrm{n}=15)$ dan pneumonia nontuberkulosis ( $n=14$ ) juga menjadi mimicker yang sering ditemukan disusul oleh kelainan jantung seperti cardiac heart failure (CHF). Hal lain yang menyerupai TB paru adalah aspergilloma dan metastasis dari berbagai tumor primer seperti limfoma maligna $(n=2)$, carcinoma cervix $(n=1)$, tumor sinonasal $(n=1)$, squamous cell carcinoma colli $(n=1)$, dan adenocarcinoma papillary thyroid $(n=1)$.

Selanjutnya, tabel 3 memberikan gambaran mengenai penyakit-penyakit paru yang dapat terjadi bersama-sama dengan adanya TB paru (co-existent). Penyakit terbanyak adalah tumor paru $(n=11)$ dan tumor metastasis $(n=4)$. Terdapat pula beberapa lesi yang terdapat diluar paru namun dapat dievaluasi pada CT-scan Toraks seperti spondylitis TB. Infected bronchiectasis, pneumonia, dan CHF juga menempati posisi dalam penyakit co-existent.

Tabel 3. Distribusi Diagnosis Penyakit Paru Penyerupa (Mimicker) dan Penyerta (Co-existent) oleh Klinisi

\begin{tabular}{lc}
\hline Diagnosis Penyakit Paru Klinisi & Jumlah \\
\hline Penyerupa (mimicker) & 18 \\
Tumor paru & 15 \\
Infected Bronchiectasis & 14 \\
Pneumonia & 10 \\
Cardiac heart failure (CHF) & 8 \\
Metastasis tumor lain & 4 \\
Aspergilloma & 11 \\
Penyerta (co-existent) & 8 \\
Tumor paru & 4 \\
Infected Bronchiectasis & 4 \\
Metastasis & 3 \\
Pneumonia & 2 \\
Cardiac heart failure & 1 \\
Spondylitis TB & 1 \\
Mesothelioma & 1 \\
Efusi pericard & 1 \\
Thymoma & 1 \\
Sindrom vena cava & 1 \\
Myelodysplasia refrakter & \\
\hline
\end{tabular}

Sumber: data primer 


\section{Diskusi}

Sebanyak 121 (88.8\%) dari 137 sampel yang ada ditemukan hasil pemeriksaan sputum BTA yang negatif meskipun sebagian besar gambaran CT-scan pasien memiliki lesi yang cukup luas dan gejala klinis pasien sesuai dengan gejala TB paru. Hal ini menunjukkan bahwa pemeriksaan sputum BTA belum dapat menjadi pemeriksaan penentu yang baik dalam menentukan ada atau tidaknya TB paru. Hal ini sesuai dengan penelitian sebelumnya, ditemukan bahwa pemeriksaan sputum BTA hanya memiliki sensitivitas setinggi $62 \%$, dengan hasil negatif palsu terbanyak apabila jumlah bakteri kurang dari 10,000 organisme per 1 mililiter sampel sputum. Jumlah sampel yang banyak, keterbatasan fasilitas, dan kemampuan personil juga dapat menyebabkan penurunan sensitifitas pemeriksaan sputum BTA. Meskipun sampel yang memiliki hasil sputum BTA positif hanya $16(11.6 \%)$ sampel, namun jumlah sampel yang pada akhirnya terdiagnosis sebagai tuberkulosis paru dan mendapatkan OAT mencapai 61 (44.5\%) sampel dari keseluruhan jumlah sampel. Pengambilan keputusan ini ditunjang dengan kondisi klinis pasien, hasil pemeriksaan kultur, Gen X-pert, maupun pemeriksaan BTA yang menggunakan spesimen selain sputum seperti bilasan bronchus, bilasan lambung, cairan pleura, hingga cairan pericard (Dhingra, 2003; Desikan, 2013).

Secara demografis, TB lebih banyak ditemukan pada laki-laki yaitu sebanyak 83 (60.50\%). Hal ini sesuai dengan penelitian metaanalisis yang dilakukan oleh Horton, K.C dkk. dimana didapatkan prevalensi TB sebanyak dua kali lipat pada laki-laki dibandingkan perempuan, Hal ini disebabkan oleh berbagai faktor seperti kurangnya kesadaran laki-laki untuk mencari pengobatan secara dini akibat persepsi "maskulinitas" dimana laki-laki lebih jarang mengeluhkan penyakit pada fase awal, sehingga menyebabkan temuan TB menjadi lebih lama daripada perempuan. Selain itu, pada berbagai penyuluhan kesehatan dan kegiatan screening, partisipasi laki-laki lebih rendah daripada wanita (Horton, 2016).

Berdasarkan usia, sampel terdistribusi lebih banyak pada usia diatas 40 tahun yaitu sebanyak 102 (74.45\%) dibandingkan dengan usia dibawah 40 tahun. Pada penelitian ini usia sampel termuda dan paling tua adalah 6 tahun dan 81 tahun. Distribusi usia ini sejalan dengan data statistik penderita TB di Amerika Serikat pada tahun 2016 yang menunjukkan adanya peningkatan insidens TB seiring dengan meningkatnya usia dengan usia 5-14 tahun hanya sebanyak < 1 kasus / 100,000 dan meningkat hingga 6.4 kasus / 100,000 pada usia $\geq 65$ tahun (CDC, 2016).

Pada penelitian ini, tampak hubungan yang signifikan antara gambaran Tree-in-bud dan lymphadenopathy terhadap diagnosis TB paru oleh klinisi. Meskipun limfadenopati lebih sering ditemukan pada kasus TB anak, namun di India dan negara berkembang lainnya, TB selalu menjadi diagnosis banding pertama bagi pasienpasien dengan limfadenopati kronik. Selain itu, limfadenopati yang terdapat pada area toraks juga sering disertai dengan limfadenopati perifer (peripheral lymphadenopathy) yang dapat teraba oleh klinisi sehingga menjadi salah satu faktor penting yang digunakan klinisi dalam menegakkan diagnosis TB (Thakkar, 2016; Mohseni, 2014).

Pada berbagai penelitian, pola Tree-inbud dapat terjadi pada berbagai penyakit selain TB, penyakit saluran nafas perifer seperti infeksi oleh bakteri, jamur, virus, atau parasit, kelainan kongenital, kelainan idiopatik (obliterative 
bronchiolitis dan panbronchiolitis), aspirasi, kelainan immunologi, kelainan jaringan ikat, dan penyakit vaskuler paru perifer seperti emboli paru akibat neoplasma. Meskipun demikian, keberadaan Tree-in-bud pada pasien TB paru merupakan tanda aktifnya suatu TB yang akan bermanifestasi pada gejala klinis dan memberikan petunjuk bagi klinisi dalam menegakkan diagnosis TB aktif (Rossi, 2005; Khajotia, 2013).

Pada penelitian ini ditemukan bahwa tiga penyakit paru terbanyak yang dapat menyertai dan menyerupai TB paru yang terbanyak adalah tumor paru, infected bronchiectasis dan pneumonia. Hal ini sesuai dengan penelitian sebelumnya oleh Bhatt dkk yang menyatakan sulitnya membedakan TB dan tumor paru akibat kesamaan gejala klinis dan demografis pasien, selain itu, TB paru juga menyebabkan inflammasi kronik dan fibrosis yang lama sehingga dapat menginduksi terjadinya mutase genetik dan alternasi yang menyebabkan terbentuknya tumor paru (Bhatt, 2012; Keikha, 2018).

Penelitian sebelumnya telah membahas mengenai sulitnya membedakan TB paru dan pneumonia non-tuberkulosis terutama di area endemik dengan Streptococcus pneumoniae sebagai penyebab terbanyak pneumonia non-TB di berbagai negara. Meskipun TB dapat bermanifestasi dengan gejala klasik seperti anorexia, turunnya berat badan, demam ringan, keringat malam, dan hemoptysis, namun gejalagejala tersebut juga sering ditemukan pada pneumonia akut/subakut sehingga menyulitkan dalam membedakan kedua penyakit ini. Selain itu, rendahnya sensitivitas pemeriksaan sputum BTA menyebabkan penegakan diagnosis TB dengan hasil sputum BTA negatif banyak dilakukan. Tidak adanya keharusan memeriksa kultur dan pemeriksaan molekuler TB dalam algoritma penegakan diagnosis TB dapat menyebabkan kecenderungan overdiagnosis TB di berbagai negara (Naderi, 2017; Claassens, 2012).

Penelitian ini mengalami keterbatasan dalam investigasi patogen yang menyebabkan ditegakkannya diagnosis infected bronchiectasis oleh klinisi. Keterbatasan ini perlu diselesaikan dengan dilakukannya penelitian lebih lanjut yang disertai dengan pemeriksaan laboratorium yang lebih lengkap.

\section{Simpulan}

Dari 12 variabel gambaran CT-scan toraks yang dinilai, hanya didapatkan dua kesesuaian yang bermakna antara gambaran morfologi lesi lymphadenopathy dan Tree-in-bud dengan diagnosis tuberkulosis paru aktif oleh klinisi. Dalam penelitian ini juga ditemukan bahwa penyerupa dan penyerta TB yang paling banyak adalah tumor paru, infected bronchiectasis, pneumonia dan metastasis.

Banyaknya variasi yang tidak khas dari gambaran CT-scan toraks pasien TB paru di rumah sakit rujukan tersier membuat penegakan diagnosis TB paru menjadi lebih rumit. Dibutuhkan ketelitian dan kerjasama yang baik antara ahli radiologi dengan klinisi untuk bersama-sama menegakkan diagnosis TB paru secara tepat. Pengetahuan mengenai mimicker dan co-existent TB paru serta tersedianya fasilitas laboratorium yang lebih mutakhir diperlukan untuk meningkatkan kecurigaan dan kemampuan investigasi terhadap kemungkinan diagnosis lain untuk mencegah overdiagnosis maupun underdiagnosis TB paru di rumah sakit rujukan tersier. 


\section{Daftar Pustaka}

Bhatt M, Kant S \& Bhaskar R. 2012. Pulmonary tuberculosis as differential diagnosis of lung cancer. South Asian journal of cancer, $1(1), \quad 36-42 . \quad$ doi:10.4103/2278$330 \times .96507$.

Center for Disease Control and Prevention (CDC). 2016. TB Case Rates by Age Group and Sex. United States, 2016. Retrieved from: https://www.cdc.gov/tb/statistics/surv/surv 2016/default.htm,

Claassens MM. 2012. Overdiagnosis of and treatment initiation delay in smearnegative pulmonary tuberculosis patients. Public health action, 2(4), 100. doi:10.5588/pha.12.0095.

Desikan P. 2013. Sputum smear microscopy in tuberculosis: is it still relevant? The Indian journal of medical research, 137(3), 442444.

Dhingra VK, Aggarwal N, Rajpal S, Aggarwal JK, Gaur SN. 2003. Validity and Reliability of Sputum Smear Examination as Diagnostic and Screening Test for Tuberculosis. Indian Journal of Allergy Asthma Immunology, 17(2).

Horton KC, MacPherson P, Houben RM, White RG \& Corbett EL. 2016. Sex Differences in Tuberculosis Burden and Notifications in Low- and Middle-Income Countries: A Systematic Review and Meta-analysis. PLoS medicine, 13(9), e1002119. doi:10.1371/journal.pmed.1002119.

Icksan A, Faisal A, Syahruddin E. 2017. The Accuracy of Aziza's Scoring System in Limited Slice Non-Enhanced Thoracic CT for The Diagnosis of Adult Pulmonary TB. Medical Journal of Indonesia. Http://dx.doi.org/10.13181/mjl.v26l1.1432.
Keikha M \& Esfahani BN. 2018. The Relationship between Tuberculosis and Lung Cancer. Advanced biomedical research, 7, 58. doi:10.4103/abr.abr_182_17.

Kementrian Kesehatan Republik Indonesia. 2014. Pedoman Nasional Pengendalian TB. Halaman 16. Accessed on: 9/24/2018. Available online: http://www.tbindonesia.or.id/opendir/Buku /bpn_p-tb_2014.pdf.

Khajotia RR, Poovaneswaran S. 2013. Pulmonary Tuberculosis Manifesting as "Tree-in-bud" Opacities on Chest Radiography. Family Medicine and Community Health: Case Study.1(1):5355.

Lee SW, Jang YS, Park CM, Koh WJ, Yim JJ, Jeon K. 2010. The Role of Chest CT Scanning in TB Outbreak Investigation. Chest. DOI: 10.1378/chest.09-1513.

Menteri Kesehatan Republik Indonesia. 2014. Peraturan Menteri Kesehatan Republik Indonesia Nomor 56 Tahun 2014 tentang Klasifikasi dan Perizinan Rumah Sakit. Hal.6.

Mohseni S, Shojaiefard A, Khorgami Z, Alinejad S, Ghorbani A \& Ghafouri A. 2014. Peripheral lymphadenopathy: approach and diagnostic tools. Iranian journal of medical sciences, 39(2 Suppl), 158-170.

Naderi $H$, Sheybani $F$, Erfani SS, Amiri B \& Nooghabi MJ. 2017. The mask of acute bacterial pneumonia may disguise the face of tuberculosis. Electronic physician, 9(3), 3943-3949. doi:10.19082/3943.

Rossi SE, Franquet T, Volpacchio M, Gimenez A, Aguilar G. 2005. Tree-in-bud Pattern at Thin-Section CT of the Lungs: RadiologicPathologic Overview. RSNA Education 


\section{Exhibits.}

https://doi.org/10.1148/rg.253045115.

Sugihantono A. 2018. Kebijakan dan Langkah Operasional Dalam Eliminasi TBC, Penurunan Stunting dan Peningkatan Imunisasi Tahun 2018. Rakerkesnas. Hal.1-3.

Thakkar K, Ghaisas SM \& Singh M. 2016. Lymphadenopathy: Differentiation between Tuberculosis and Other NonTuberculosis Causes like Follicular Lymphoma. Frontiers in public health, 4, 31. doi:10.3389/fpubh.2016.00031.

WHO. 2018. Global TB Report. Accessed On: 9/24/2018. Available online: https://www.who.int/tb/publications/global _report/en/. 